\title{
Diagnosis and clinical severity markers of bullous pemphigoid
}

\section{Enno Schmidt* and Detlef Zillikens}

\author{
Address: Department of Dermatology, University of Lübeck, Ratzeburger Allee 160, D-23538 Lübeck, Germany \\ *Corresponding author: Enno Schmidt (enno.schmidt@uk-sh.den) \\ Fl000 Medicine Reports 2009, I:15 (doi: 10.3410/MI-15) \\ The electronic version of this article is the complete one and can be found at: http://FI000.com/Reports/Medicine/content/I/I5
}

\begin{abstract}
The use of a broad spectrum of novel detection systems for autoantibodies to the basement membrane proteins BPI80 and BP230 has greatly facilitated the diagnosis of bullous pemphigoid, which most likely explains its increasing incidence in central Europe. Because the pathogenic relevance of antibodies to human BPI80 has been convincingly shown both in vitro and in vivo, repeated testing for these antibodies appears to be helpful in guiding treatment decisions during the course of the disease.
\end{abstract}

\section{Introduction and context}

Bullous pemphigoid (BP) is the most frequent autoimmune bullous disorder and is clinically characterized by tense blisters and crusts on erythematous or apparently uninvolved skin. Direct immunofluorescence (IF) microscopy of a perilesional skin biopsy that typically reveals linear deposits of complement component 3 (C3) and/or immunoglobulin $\mathrm{G}(\mathrm{IgG})$ at the basal membrane zone $(\mathrm{BMZ})$ is still the diagnostic gold standard. The most sensitive substrate for screening of serum autoantibodies in subepidermal blistering autoimmune diseases is 1 molar sodium chloride $(1 \mathrm{M}$ $\mathrm{NaCl})$ split human skin. In $\mathrm{BP}$, the circulating IgG autoantibodies label the epidermal side of the artificial split. These autoantibodies are directed against two hemidesmosomal proteins, BP180 and BP230 [1,2]. BP180, also known as type XVII collagen or BP antigen 2 , is a transmembrane glycoprotein of about 1500 amino acids which ultrastructurally spans the lamina lucida before kinking back from the lamina densa to the lamina lucida. In contrast, BP230 is an intracellular constituent of the hemidesmosomal plaque and belongs to the plakin family of proteins. In recent years, analysis of the fine specificities of various isotypes of autoantibodies against the two target antigens has led to both better diagnostic tools and new insights into the pathogenicity of autoantibodies in $\mathrm{BP}$.

\section{Recent advances \\ Diagnosis of bullous pemphigoid}

For more than a decade, B-cell epitopes have been known to be unequally distributed on BP180 in BP. The extracellular portion of the 16th non-collagenous (NC16A) domain was shown to be recognized by about $80 \%$ of BP sera [3]. It then became obvious that the majority of BP patients also raise antibodies against epitopes outside the NC16A domain [4-9]. Interestingly, IgG reactivity with C-terminal epitopes appeared to be associated with the presence of both skin and mucosal lesions [6-8] whereas the intracellular domain was preferentially targeted at an early clinical stage [8]. Testing for anti-BP180 antibodies outside the NC16A domain therefore is required in those patients unreactive with the immunodominant domain and has been included in our routine work-up. Most recently, the extent of phosphorylation of BP180 was shown to be important for binding of antibodies to its ectodomain [10]. Because antibodies raised against the murine homolog to the NC16A domain, expressed in Escherichia coli, induce subepidermal blisters when injected into neonatal mice, the relevance of phosphoepitopes on BP180 needs to be determined.

The other major target antigen in $\mathrm{BP}, \mathrm{BP} 230$, is recognized in between 60 and $70 \%$ of patients by enzyme-linked immunosorbent assay (ELISA) 
$[4,9,11,12]$. As for BP180, B-cell epitopes are not equally distributed but preferentially localize to the globular C-terminal domain of BP230 that mediates interaction with keratin filaments and is targeted by about $80 \%$ of BP230-reactive BP sera $[9,13,14]$. Interestingly, reactivity to BP230 was predominantly found in patients with limited BP, and only less than 5\% of BP sera exclusively recognized BP230 [4]. By the combined use of detection systems for anti-BP180 and anti-BP230 antibodies, all 49 $\mathrm{BP}$ sera were reactive in a recent multicenter prospective study [9].

The novel diagnostic assays have greatly facilitated the diagnosis of BP (Figure 1), which may explain the increased incidence of BP that was recently observed in a prospective study with patients from a well-defined region, Lower Franconia in Germany. Compared with a study of the same region 10 years earlier, the incidence of $\mathrm{BP}$ has increased from 6.6 to 13.4 new cases per million per year $[15,16]$. An even higher incidence (including all subepidermal bullous diseases) of $43 \mathrm{new}$ cases per million per year, which has increased almost fivefold within the last 10 years, was recently reported in the UK [17]. The data, however, were retrieved from a database for general practitioners and have been challenged by the report that in St. John's Institute of Dermatology, London, the diagnosis of $\mathrm{BP}$, based on direct IF microscopy, has not increased within the last decade [18].

Whereas IgG reactivity to BP180 has been studied intensively, the importance of BP180-specific antibodies of the IgA and IgE isotypes has been highlighted only recently. Indeed, the majority of $\mathrm{BP}$ sera contain IgA antibodies to BP180 and most sera of patients with linear IgA disease raise IgG anti-BP180 antibodies in addition to IgA reactivity [19]. There appears to be a spectrum of the autoimmune response against BP180, ranging from pure IgG to pure IgA reactivity, with mixtures in between. This hypothesis is supported by the observation in Uganda that younger patients with $\mathrm{BP} /$ linear IgA disease were more likely to develop IgA anti-BMZ antibodies whereas older patients tended to raise IgG autoantibodies [20]. IgE reactivity against BP180 has been reported in 30 to $95 \%$ of BP patients [21-25]. The majority of sera contain IgE reactivity to the NC16A domain, and IgE antibodies to the intracellular domain of BP180 have also been detected recently $[23,25]$.

In addition to reactivity against BP180 and BP230, antibodies to the $\alpha 6$ chain of $\alpha 6 \beta 4$ integrin and laminin 332 , also known as laminin 5, have been reported in $50 \%$ and $40 \%$ of BP patients, respectively $[26,27]$. The relevance of these findings is elusive and both findings
Figure I. Diagnostic pathway in bullous pemphigoid (BP)

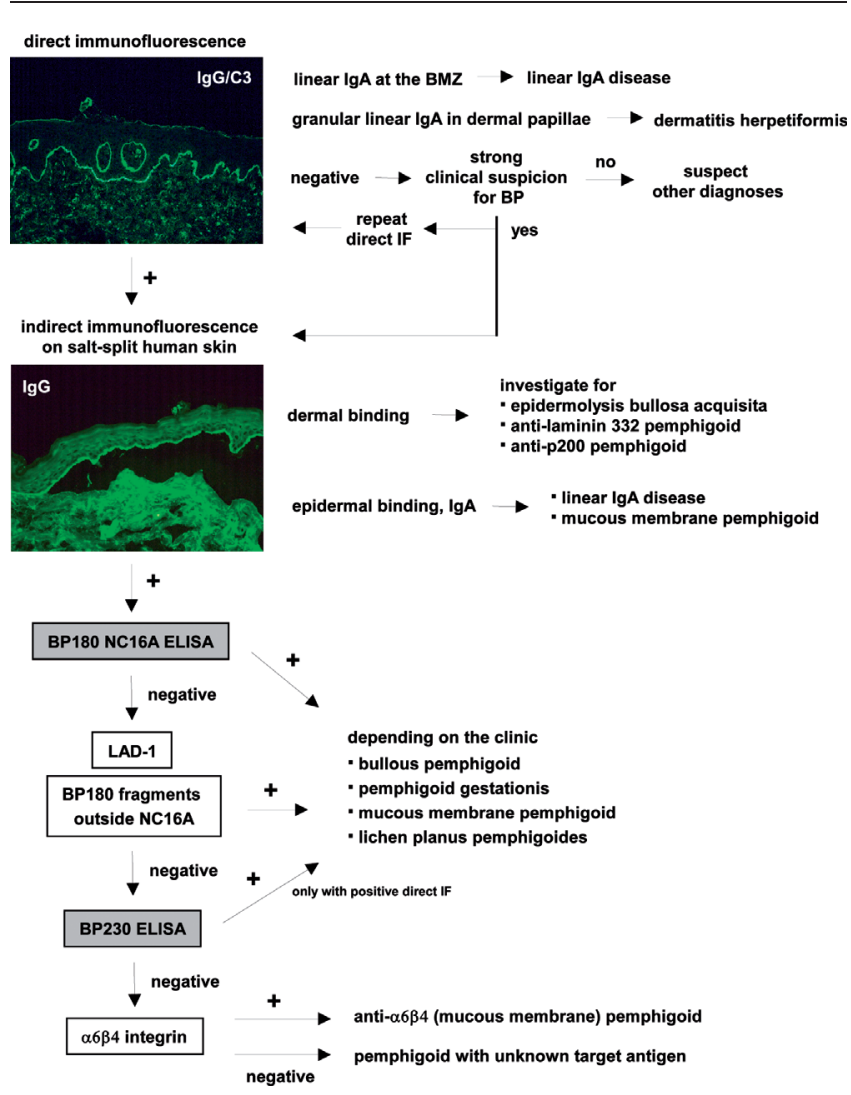

Direct immunofluorescence (IF) microscopy of a perilesional biopsy is the gold standard for the diagnosis of BP and differentiates subepidermal blistering autoimmune diseases from pemphigus. By indirect IF microscopy on I $\mathrm{M} \mathrm{NaCl}$ spilt human skin, BP patients' sera are screened for anti-basal membrane zone (BMZ) autoantibodies. Whereas sera from patients with epidermolysis bullosa acquisita, anti-laminin 332 mucous membrane pemphigoid, and anti-p200 pemphigoid label the dermal side of the artificial split, sera of BP patients bind to the blister roof. Anti-BPI80 antibodies can be detected by BPI $80 \mathrm{NCI}$ AA-specific enzyme-linked immunosorbent assay (ELISA), Western blotting with conditioned concentrated medium of cultured $\mathrm{HaCaT}$ cells, which detects reactivity against LAD-I (linear IgA disease antigen I) that corresponds to the cell-derived ectodomain of BPI80, and Western blotting with various other recombinant fragments of BPI80. Since four different entities are associated with $\lg G$ antibodies to $\mathrm{BPI} 80$, the clinical phenotype determines the final diagnosis. When no $\mathrm{BPI} 80$ reactivity is found, sera are assayed for BP230-specific antibodies that, only in conjunction with a positive direct IF microscopy and compatible clinical features support the diagnosis of BP. In case of epidermal binding by indirect IF microscopy and failure to detect IgG reactivity to both BPI 80 and BP230, testing for antibodies against $\alpha 634$ integrin is recommended (for example, by Western blotting of keratinocyte extract) [44]. The shaded boxes represent commercially available test systems. NCI6A, the extracellular portion of the 16th noncollagenous (domain).

await confirmation. A more recent report demonstrates that the detection of antibodies to laminin 332 is rather uncommon in BP [28]. 


\section{Clinical severity markers of bullous pemphigoid}

The first evidence for a pathogenic role of human antibodies to human BP180 came from the observation that levels of circulating antibodies to the NC16A domain correlate with disease activity in BP patients [29]. This notion has been corroborated in different patient populations within recent years [30-34]. Thus, the NC16A domain appears to be an important target for monitoring circulating autoantibody levels and for guiding treatment decisions; for example, the reduction of the corticosteroid dose during the course of the disease. By the use of an NC16A tetramer, a second commercially available ELISA that is a highly sensitive and specific tool for the detection of serum antibodies in BP has been established [35]. Autoantibody levels to a C-terminal stretch of BP180 have subsequently been shown to parallel clinical activity in BP [9].

The pathogenic relevance of human antibodies to human BP180 had previously been suggested in vitro when the incubation of cultured human keratinocytes and cryosections of human skin with BP IgG resulted in increased mRNA levels followed by the release of proinflammatory cytokines or dermal-epidermal separation, respectively [36,37]. Most recently, a decrease of cell-surface BP180 that led to weakened cell attachment has been observed in response to the incubation of cultured human keratinocytes with anti-BP180 antibodies [38]. In addition, in vivo data have been provided by Nishie et al. [39], who induced BP-like skin lesions by injection of IgG from BP patients into Col17 knockout mice rescued by the human ortholog.

The importance of IgE autoantibodies to BP180 NC16A has been highlighted by demonstrating a correlation between clinical activity and IgE NC16A-specific circulating antibodies that were detected in $60 \%$ of BP patients [21]. Subsequently, IgE antibodies directed against this domain were linked to both a greater extent of skin lesions and a longer time period until remission was induced [23]. These observations have been substantiated in two passive-transfer mouse models. The injection of BP IgE or an IgE-producing hybridoma against the BP180 ectodomain into human skin grafted on to athymic nude mice or SCID (severe combined immunodeficiency disease) mice, respectively, resulted in an erythematous itchy plaque, which showed dermalepidermal separation by histopathology $[40,41]$. Whether measurement of IgE anti-BP180 NC16A antibodies will be included in the routine analysis of BP sera needs to be addressed in future studies.

Whereas the pathogenic relevance of antibodies to BP180 is well established, the role of anti-BP230 reactivity is less clear. Serum levels of anti-BP230 antibodies repeatedly failed to parallel disease activity in BP patients $[4,9,12]$. In addition, experimental evidence for the pathogenicity of anti-BP230 antibodies is inconclusive and needs further exploration.

\section{Implications for clinical practice}

Direct IF microscopy of a perilesional biopsy is still regarded as the gold standard in the diagnosis of $\mathrm{BP}$. A large body of evidence, however, has been collected supporting the notion that, in a large majority of BP patients, the disease can be diagnosed serologically by the detection of BP180 NC16A-specific autoantibodies. Rarely, anti-BP180 antibodies have also been found in patients with pruritic disorders, diabetes mellitus, or dementia, even when there have been no associated clinical signs of BP and direct IF microscopy has been negative [42,43]. Usually, however, in patients with clinical lesions typical for $\mathrm{BP}$, the detection of antibodies to BP180 NC16A suffices to establish the diagnosis of $\mathrm{BP}$, whereas serum antibodies to BP230 require a positive direct IF microscopy to diagnose BP. Finally, based on our personal experience, repeated testing for serum anti-BP180 NC16A antibodies during the course of the disease may be a helpful guide for treatment decisions.

\section{Abbreviations}

$\mathrm{BMZ}$, basal membrane zone; BP, bullous pemphigoid; C3, complement component 3; ELISA, enzyme-linked immunosorbent assay; IF, immunofluorescence; IgG, immunoglobulin G; NC16A, the extracellular portion of the 16 th noncollagenous (domain).

\section{Competing interests}

The authors run a non-profit laboratory that is integrated into the Department of Dermatology at the University of Lübeck. This laboratory specializes in the diagnosis of autoimmune bullous diseases and receives sera from all over the world. In this laboratory, the test systems discussed in this report are applied.

\section{References}

I. Stanley JR, Hawley-Nelson P, Yuspa SH, Shevach EM, Katz SI: Characterization of bullous pemphigoid antigen: a unique basement membrane protein of stratified squamous epithelia. Cell 198I, 24:897-903.

2. Labib RS, Anhalt GJ, Patel HP, Mutasim DF, Diaz LA: Molecular heterogeneity of the bullous pemphigoid antigens as detected by immunoblotting. J Immunol 1986, 136: I23 I-5.

3. Zillikens D, Rose PA, Balding SD, Liu Z, Olague-Marchan M, Diaz LA, Giudice G]: Tight clustering of extracellular BP I 80 epitopes recognized by bullous pemphigoid autoantibodies. J Invest Dermatol 1997, 109:573-9.

4. Thoma-Uszynski S, Uter W, Schwietzke S, Hofmann SC, Hunziker T, Bernard P, Treudler R, Zouboulis CC, Schuler G, Borradori L, 
Hertl M: BP230- and BP I 80-specific auto-antibodies in bullous pemphigoid. J Invest Dermatol 2004, I 22: I4I3-22.

5. Perriard J, Jaunin F, Favre B, Büdinger L, Hertl M, Saurat JH, Borradori $\mathrm{L}$ : IgG autoantibodies from bullous pemphigoid (BP) patients bind antigenic sites on both the extracellular and the intracellular domains of the BP antigen I80. J Invest Dermatol 1999, I | 2:14|-7.

6. Mariotti F, Grosso F, Terracina M, Ruffelli M, Cordiali-Fei P, Sera F, Zambruno G, Mastrogiacomo A, Di Zenzo G: Development of a novel ELISA system for detection of anti-BPI80 IgG and characterization of autoantibody profile in bullous pemphigoid patients. Br J Dermatol 2004, I 5 I: 1004-10.

7. Hofmann S, Thoma-Uszynski S, Hunziker T, Bernard P, Koebnick C, Stauber A, Schuler G, Borradori L, Hertl M: Severity and phenotype of bullous pemphigoid relate to autoantibody profile against the $\mathbf{N H}_{2 \text { - }}$ and $\mathrm{COOH}$-terminal regions of the BPI80 ectodomain. J Invest Dermatol 2002, I I 9: I065-73.

8. Di Zenzo G, Grosso F, Terracina M, Mariotti F, De Pità $O$, Owaribe K, Mastrogiacomo A, Sera F, Borradori L, Zambruno G: Characterization of the anti-BPI80 autoantibody reactivity profile and epitope mapping in bullous pemphigoid patients. J Invest Dermatol 2004, I 22:103-10.

9. Di Zenzo G, Thoma-Uszynski S, Fontao L, Calabresi V, Hofmann SC, Hellmark T, Sebbag N, Pedicelli C, Sera F, Lacour JP, Wieslander J, Bruckner-Tuderman L, Borradori L, Zambruno G, Hertl M: Multicenter prospective study of the humoral autoimmune response in bullous pemphigoid. Clin Immunol 2008, I 28:4I5-26.

10. Zimina EP, Hofmann SC, Fritsch A, Kern JS, Sitaru C, BrucknerTuderman L: Bullous pemphigoid autoantibodies preferentially recognize phosphoepitopes in collagen XVII. J Invest Dermatol 2008, I 28:2736-9.

II. Yoshida M, Hamada T, Amagai M, Hashimoto K, Uehara R, Yamaguchi K, Imamura K, Okamoto E, Yasumoto S, Hashimoto T: Enzyme-linked immunosorbent assay using bacterial recombinant proteins of human BP230 as a diagnostic tool for bullous pemphigoid. J Dermatol Sci 2006, 4I:2I-30.

12. Kromminga A, Sitaru C, Hagel C, Herzog S, Zillikens D: Development of an ELISA for the detection of autoantibodies to BP230. Clin Immunol 2004, I I I: |46-52.

13. Hamada T, Nagata Y, Tomita M, Salmhofer W, Hashimoto T: Bullous pemphigoid sera react specifically with various domains of BP230, most frequently with C-terminal domain, by immunoblot analyses using bacterial recombinant proteins covering the entire molecule. Exp Dermatol 200I, 10:256-63.

14. Skaria M, Jaunin F, Hunziker T, Riou S, Schumann H, BrucknerTuderman L, Hertl M, Bernard P, Saurat JH, Favre B, Borradori L: IgG autoantibodies from bullous pemphigoid patients recognize multiple antigenic reactive sites located predominantly within the $B$ and $C$ subdomains of the COOH-terminus of BP230. J Invest Dermatol 2000, I I 4:998-1004.

15. Bertram F, Bröcker EB, Zillikens D, Schmidt E: Prospective analysis of the incidence of autoimmune bullous disorders in Lower Franconia, Germany [in German]. J Dtsch Dermatol Ges 2009, Jan 19. [Epub ahead of print].

16. Zillikens D, Wever S, Roth A, Weidenthaler-Barth B, Hashimoto T, Brocker EB: Incidence of autoimmune subepidermal blistering dermatoses in a region of central Germany. Arch Dermatol 1995, | 3 |:957-8.

17. Langan SM, Smeeth L, Hubbard R, Fleming KM, Smith CJ, West J: Bullous pemphigoid and pemphigus vulgaris-incidence and mortality in the UK: population based cohort study. BMJ 2008,, 337:al80.

FI000 Factor 3.0 Recommended

Evaluated by Detlef Zillikens with Enno Schmidt 6 Aug 2008

18. Groves RW, Bhogal B, Taghipour K, Caposciutti P, Saha M: Bullous pemphigoid: is the incidence of pemphigoid really increasing? BMJ 2008, 337:a I I38.

19. Kromminga A, Scheckenbach C, Georgi M, Hagel C, Arndt R, Christophers E, Bröcker EB, Zillikens D: Patients with bullous pemphigoid and linear IgA disease show a dual IgA and IgG autoimmune response to BP I80. J Autoimmun 2000, I 5:293-300.

20. Mulyowa GK, Jaeger G, Kabakyenga J, Brocker EB, Zillikens D, Schmidt E: Autoimmune subepidermal blistering diseases in Uganda: correlation of autoantibody class with age of patients. Int J Dermatol 2006, 45:1047-52.

21. Dopp R, Schmidt E, Chimanovitch I, Leverkus M, Brocker EB Zillikens D: IgG4 and IgE are the major immunoglobulins targeting the NCI6A domain of BPI80 in Bullous pemphigoid: serum levels of these immunoglobulins reflect disease activity. J Am Acad Dermatol 2000, 42:577-83.

22. Ishiura $N$, Fujimoto $M$, Watanabe $R$, Nakashima $H$, Kuwano $Y$, Yazawa N, Echigo T, Okochi H, Tamaki K: Serum levels of IgE antiBP I 80 and anti-BP230 autoantibodies in patients with bullous pemphigoid. J Dermatol Sci 2008, 49:|53-6|

23. Iwata $\mathrm{Y}$, Komura K, Kodera M, Usuda T, Yokoyama Y, Hara T, Muroi E, Ogawa F, Takenaka M, Sato S: Correlation of IgE autoantibody to BPI80 with a severe form of bullous pemphigoid. Arch Dermatol 2008, I44:4I-8.

Changes Clinical Practice

FI000 Factor 3.2 Recommended

Evaluated by Akira Ishiko 4 Feb 2008, Cassian Sitaru I5 May 2008

24. Fairley JA, Fu CL, Giudice GJ: Mapping the binding sites of antiBPI 80 immunoglobulin E autoantibodies in bullous pemphigoid. J Invest Dermatol 2005, I 25:467-72.

25. Dresow SK, Sitaru C, Recke A, Oostingh GJ, Zillikens D, Gibbs BF: IgE autoantibodies against the intracellular domain of BPI 80. Br J Dermatol 2008, Sep 19. [Epub ahead of print].

26. Kiss M, Perényi A, Marczinovits I, Molnár J, Dobozy A, Kemény L, Husz S: Autoantibodies to human alpha6 integrin in patients with bullous pemphigoid. Ann N Y Acad Sci 2005, I 05 I: 104-10.

27. Bekou V, Thoma-Uszynski S, Wendler O, Uter W, Schwietzke S, Hunziker T, Zouboulis CC, Schuler G, Sorokin L, Hertl M: Detection of laminin 5-specific auto-antibodies in mucous membrane and bullous pemphigoid sera by ELISA. J Invest Dermatol 2005, 1 24:732-40.

28. Lazarova Z, Salato VK, Lanschuetzer CM, Janson M, Fairley JA, Yancey KB: IgG anti-laminin-332 autoantibodies are present in a subset of patients with mucous membrane, but not bullous, pemphigoid. J Am Acad Dermatol 2008, 58:95I-8.

FI000 Factor 3.0 Recommended

Evaluated by Detlef Zillikens 2 May 2008

29. Schmidt E, Obe K, Brocker EB, Zillikens D: Serum levels of autoantibodies to BPI80 correlate with disease activity in patients with bullous pemphigoid. Arch Dermatol 2000, 136: $174-8$

30. Feng S, Wu Q, Jin P, Lin L, Zhou W, Sang H, Shao C: Serum levels of autoantibodies to BPI80 correlate with disease activity in patients with bullous pemphigoid. Int J Dermatol 2008, 47:225-8.

31. Amo Y, Ohkawa T, Tatsuta M, Hamada Y, Fujimura T, Katsuoka K, Hashimoto T: Clinical significance of enzyme-linked immunosorbent assay for the detection of circulating anti-BPI80 autoantibodies in patients with bullous pemphigoid. J Dermatol Sci 200I, 26:14-8.

32. Tsuji-Abe Y, Akiyama M, Yamanaka Y, Kikuchi T, Sato-Matsumura KC, Shimizu $\mathrm{H}$ : Correlation of clinical severity and ELISA indices for the NCI6A domain of BPI80 measured using BPI80 ELISA kit in bullous pemphigoid. J Dermatol Sci 2005, 37:145-9.

33. Kobayashi M, Amagai M, Kuroda-Kinoshita K, Hashimoto T, Shirakata Y, Hashimoto K, Nishikawa T: BPI80 ELISA using bacterial recombinant $\mathrm{NCI}$ a protein as a diagnostic and monitoring tool for bullous pemphigoid. J Dermatol Sci 2002, 30:224-32.

34. Izumi T, Ichiki Y, Esaki C, Kitajima Y: Monitoring of ELISA for anti-BPI80 antibodies: clinical and therapeutic analysis of steroid-treated patients with bullous pemphigoid. I Dermatol 2004, 3 I:383-91

35. Sitaru C, Dähnrich C, Probst C, Komorowski L, Blöcker I, Schmidt E, Schlumberger W, Rose C, Stöcker W, Zillikens D: Enzyme-linked 
immunosorbent assay using multimers of the 16th noncollagenous domain of the BPI80 antigen for sensitive and specific detection of pemphigoid autoantibodies. Exp Dermatol 2007, 16:770-7.

36. Schmidt E, Reimer S, Kruse N, Jainta S, Bröcker EB, Marinkovich MP, Giudice G], Zillikens D: Autoantibodies to BPI80 associated with bullous pemphigoid release interleukin- 6 and interleukin-8 from cultured human keratinocytes. J Invest Dermatol 2000, II 5:842-8.

37. Herrero-González JE, Brauns O, Egner R, Rönspeck W, Mascaró JM Jr., Jonkman MF, Zillikens D, Sitaru C: Immunoadsorption against two distinct epitopes on human type XVII collagen abolishes dermalepidermal separation induced in vitro by autoantibodies from pemphigoid gestationis patients. Eur J Immunol 2006, 36: I039-48.

38. Iwata H, Kamio N, Aoyama Y, Yamamoto Y, Hirako Y, Owaribe K, Kitajima Y: IgG from Patients with Bullous Pemphigoid Depletes Cultured Keratinocytes of the 180-kDa Bullous Pemphigoid Antigen (Type XVII Collagen) and Weakens Cell Attachment. J Invest Dermatol 2009, Jan 29. [Epub ahead of print].

39. Nishie W, Sawamura D, Goto M, Ito K, Shibaki A, McMillan JR, Sakai K, Nakamura H, Olasz E, Yancey KB, Akiyama M, Shimizu H: Humanization of autoantigen. Nat Med 2007, 13:378-83.

FI000 Factor 8.3 Exceptional

Evaluated by Aimee Payne 16 Apr 2007, Cassian Sitaru 24 Apr 2007, Takashi Hashimoto 30 May 2007, Stefan Martin 29 Aug 2007

40. Zone JJ, Taylor T, Hull C, Schmidt L, Meyer L: IgE basement membrane zone antibodies induce eosinophil infiltration and histological blisters in engrafted human skin on SCID mice. J Invest Dermatol 2007, 127:1167-74.

FI000 Factor 4.8 Must Read

Evaluated by Cassian Sitaru 8 Aug 2007, Takashi Hashimoto 20 Jun 2008

4I. Fairley JA, Burnett CT, Fu CL, Larson DL, Fleming MG, Giudice G]: A pathogenic role for IgE in autoimmunity: bullous pemphigoid IgE reproduces the early phase of lesion development in human skin grafted to nu/nu mice. J Invest Dermatol 2007, |27:2605-II.

FI000 Factor 4.8 Must Read

Evaluated by Yumi Aoyama 28 Aug 2007, Stefan Martin I2 Sep 2007

42. Jedlickova H, Racovska J, Niedermeier A, Feit J, Hertl M: Antibasement membrane zone antibodies in elderly patients with pruritic disorders and diabetes mellitus. Eur J Dermatol 2008, 18:534-8.

43. Foureur N, Mignot S, Senet P, Verpillat P, Picard-Dahan C, Crickx B, Labarre C, Nicaise-Roland P, Descamps V: Correlation between the presence of type-2 anti-pemphigoid antibodies and dementia in elderly subjects with no clinical signs of pemphigoid [in French]. Ann Dermatol Venereol 2006, 133:439-43.

44. Leverkus M, Bhol K, Hirako Y, Pas H, Sitaru C, Baier G, Bröcker EB, Jonkman MF, Ahmed AR, Zillikens D: Cicatricial pemphigoid with circulating autoantibodies to beta 4 integrin, bullous pemphigoid 180 and bullous pemphigoid 230. $\mathrm{Br}$ 」 Dermatol 200I, 145:998-1004. 